MONIKA MACIEJEWSKA

Wydział Nauk Społecznych

Uniwersytet Warmińsko-Mazurski w Olsztynie

ORCID ID: http://orcid.org/oooo-ooo3-2945-0884
Forum Pedagogiczne $2018 / 2$

Wpłynęło: 30.03.2018

Zatwierdzono do druku: 26.09.2018 DOI: $10.21697 / \mathrm{fp} .2018 .2 .11$

\title{
BADANIA EWALUACYJNE W EDUKACJI JAKO ŹRÓDŁO WIEDZY PEDAGOGICZNEJ
}

\begin{abstract}
Streszczenie: $\mathrm{W}$ debatach podejmowanych w obszarze pedagogiki ogólnej istotne miejsce zajmują kwestie metodologiczne, związane z poszukiwaniem nowych możliwości wytwarzania wiedzy pedagogicznej. Wynika to z kilku przesłanek. Przede wszystkim jest to odpowiedzią na zmiany zachodzące w szeroko rozumianej edukacji i stawianych na nowo pytań o użyteczność wiedzy pedagogicznej. Stanowi też istotny fragment budowania tożsamości dyscypliny, wpisujący się w dynamiczny proces jej wewnętrznych zmian i rozwoju. Pojawiają się nowe pytania w obszarze konceptualizacji przedmiotu badań, zarysowywane są również nowe sposoby formułowania problemów badawczych, a to wymaga nowych rozwiązań metodologicznych. Prezentowane opracowanie pomyślane zostało jako głos w dyskusji nad usytuowaniem badań określanych jako praktyczne/ stosowane w odniesieniu do pojawiających się potrzeb praktyki i teorii pedagogicznej. Szczególną uwagę zwrócono na badania ewaluacyjne w edukacji, które zdaniem autorki generują wiele możliwości rozpoznawania ważkich kwestii pedagogicznych.
\end{abstract}

Słowa kluczowe: badania stosowane, ewaluacja w edukacji, pedagogika ogólna, metodologia nauk pedagogicznych.

\section{Wprowadzenie}

Przyjmując za punkt wyjścia określenie, że „pedagogika ogólna nie tylko opisuje praktykę edukacji, ale stanowi formę naukowej autorefleksji samej pedagogiki" (Rubacha 2003, s. 22), wyraźnie wpisujemy w obszar dociekań tej subdyscypliny obok szeroko zakrojonych analiz teoretycznych także kwestie metodologiczne, szczególnie istotne dla budowania jej statusu naukowego. Jak podkreśla Stanisław Palka, refleksja nad metodologią badań w pedagogice powinna być procesem ciągłym. Teza ta została poparta szeregiem argumentów, rozpoczynając od ogólnych kwestii rozwoju nauk pedagogicznych i zmian w zakresie ich uprawiania, ale także zmian w samej dziedzinie poznania pedagogicznego, czyli szeroko rozumianej edukacji, poprzez ewoluujące podejścia do kwestii użyteczności 
pedagogiki, jej praktycznego charakteru i społecznej istotności, aż po zmiany zachodzące w społeczności badaczy, otwierających się na poszukiwanie nowych sposobów uprawiania nauki w rzadko wykorzystywanych dotychczas przestrzeniach (Palka 2010). W tym kontekście rozważania obejmujące metodologię badań podejmowanych nie tylko nad edukacją, ale przede wszystkim w edukacji i dla edukacji (Czerepaniak-Walczak 1997) stają się potrzebną, jeśli nie wręcz niezbędną częścią dyskursów współczesnej pedagogiki. Interesujący trop w tym obszarze poddaje Teresa Hejnicka-Bezwińska, odnosząc się do zmian w pojmowaniu praxis i wynikających z tego konsekwencji teoretyczno-metodologicznych. Zdaniem autorki, „zmiany w konceptualizacji przedmiotu badań pedagogicznych tworzą nowe ramy i dostarczają nowych inspiracji dla problemów badawczych możliwych do sformułowania, a te z kolei wyznaczają poszukiwania, wybory i decyzje metodologiczne" (Hejnicka-Bezwińska 2017, s. 95), którym warto przyglądać się z różnych perspektyw.

Prezentowane opracowanie pomyślane zostało jako głos w dyskusji nad usytuowaniem badań określanych jako praktyczne/stosowane w odniesieniu do pojawiających się potrzeb praktyki i teorii pedagogicznej. Wpisuje się zatem w podejmowaną na forum pedagogiki ogólnej dyskusję o związkach teorii z praktyką, wynikających z praktycznego charakteru pedagogiki jako nauki. Szczególną uwagę zwrócono na badania ewaluacyjne w edukacji, które zdaniem autorki generują wiele możliwości rozpoznawania ważkich kwestii pedagogicznych.

\section{Tworzenie wiedzy potrzebnej praktyce}

Pedagogika jako nauka teoretyczno-praktyczna nieustannie zmaga się z rozstrzyganiem relacji pomiędzy teorią a praktyką, które przybierają różne formy w zależności od zmieniających się warunków badawczych i podejść do uprawiania pedagogiki. Główny nurt zmian związany z przechodzeniem od pozytywistycznego do postpozytywistycznego modelu uprawiania nauki (Hejnicka-Bezwińska 2017) uruchomił dyskursy, które wcześniej nie miały szansy wybrzmieć w polskiej pedagogice. Pojawiły się m.in. próby sytuowania praktyczności pedagogiki w szerszej debacie na temat etyczności i zaangażowania edukacyjnej działalności (por. „Teraźniejszość - Człowiek - Edukacja” 2001, numer specjalny), co skutkowało re-definicjami praktyczności dyscypliny, proponowanymi m.in. przez Zbigniewa Kwiecińskiego (2000), Joannę Rutkowiak (2001) czy Romana Lepperta (2001). Zwrócono uwagę na potrzebę budowania w pedagogice zarówno teorii najszerszego zasięgu, o dużym stopniu ogólności, jak też teorii średniego i wąskiego zasięgu (Rubacha 2008). Interesująca dyskusja, która ujawniła wielość podejść do tworzenia wiedzy pedagogicznej, prowadzona była również na III Seminarium Metodologii Pedagogiki (por. Piekarski i in. 2010). Przypomniano o sprzężeniu zwrotnym między praktyką a teorią $\mathrm{w}$ badaniach, gdzie impulsem do budowania teorii są potrzeby praktyki, ta zaś zwrotnie staje się sprawdzianem dla teorii (Rubacha 2008). Upomniano się 
o namysł nad różnymi perspektywami stosowanymi w badaniach pedagogicznych, szczególnie perspektywą interpretatywną w badaniach jakościowych, pozwalającymi na rozpoznawanie innych niż dotąd aspektów rzeczywistości pedagogicznej (Urbaniak-Zając 2008). Pojawiły się też głosy nawiązujące bezpośrednio do dewaluacji badań empirycznych w pedagogice, szczególnie zaś tych, które podejmują zagadnienia praktyczne. Teresa Bauman podkreśliła, że należy zastanowić się nad ważnością badań praktycznych „poszukujących najlepszych rozwiązań i formułujących wnioski, które można traktować jako odpowiedzi bądź argumenty na rzecz zastosowania konkretnych metod, ale także na rzecz budowania wiedzy pedagogicznej na solidnych podstawach empirycznych" (Bauman 2017, s. 139). Nieco z boku toczy się również spór o to, w jaki sposób określać badania bezpośrednio nawiązujące do praktyki edukacyjnej, gdyż kategoria „badania stosowane” staje się wyraźnie niewystarczająca w odniesieniu ewolucji tego rodzaju badań, postępujących w stronę modeli partycypacyjnych.

Wyraźne upominanie się o przyznanie równorzędnego miejsca wiedzy pedagogicznej, poszukiwanej i tworzonej w odniesieniu do konkretnych problemów praktycznych, może przynieść jednak różnorakie skutki w zależności od wyjściowej koncepcji rozumienia wiedzy, a dokładniej od tego, czy przyjmujemy tradycyjny podział na wiedzę teoretyczną (episteme) i praktyczną (techne) (za: Mizerek 2010), czy jako punkt wyjścia potraktujemy Arystotelesowskie rozumienie phronesis odczytywane w kategoriach rozważnego wyboru (Arystoteles 1983), czyli zdolności używania sądów w sytuacjach, które wymagają refleksji nad działaniem. Phronesis w tym kontekście odnosi się do jedności teorii i praktyki. Z wiedzą naukową zazwyczaj utożsamiana jest episteme - uzasadniona, uogólniona, pewna wiedza o rzeczywistości. Techne, czyli wiedza praktyczna, która pozwala przede wszystkim na dobór skutecznych środków realizacji założonych celów, jest zdecydowanie niżej ceniona w środowiskach naukowych ${ }^{1}$. Takie ujęcie generuje budowanie hierarchicznych relacji. Głównie odnoszą się one do procesu badawczego, w którym nadrzędnym i podstawowym elementem staje się teoria, stanowiąca podstawę do wyprowadzania koncepcji i procedur działania. Podobne podziały zaznaczają się też wyraźnie w relacjach między przedstawicielami episteme - naukowcami i techne - praktykami. Jak zauważa Mirosława Nowak-Dziemianowicz, w opartych na tym układzie naukach społecznych, podporządkowanych technicznej

1 Rozdzielność wiedzy, wynikająca z przyjęcia jako punktu wyjścia episteme i techne, stała się wytyczną do wyróżnienia najbardziej rozpowszechnionego w typologiach metodologicznych podziału na badania teoretyczne, określane także jako podstawowe (basic research) oraz badania praktyczne nazywane stosowanymi (applied research) (por. Neuman 2014; Konarzewski 2000, Rubacha 2012 i in.). W. L. Neuman jako główne obszary różnicowań badań podstawowych i stosowanych podał sposób korzystania z ich wyników badań oraz główną grupę odbiorców, do których trafia zdobyta wiedza. Podkreśla jednocześnie, że w jego opinii podział ten nie tworzy sztywnej siatki ról funkcjonowania badawczego. Uważa, że badacze uprawiają często oba typy badań lub przechodzą od jednego do drugiego na różnych etapach kariery (Neuman 2014). 
i pozytywistycznej wizji rzeczywistości, prawdziwa natura praxis została zniekształcona, zdominowana przez rozumowanie techniczne i zdegradowana do technicznej kontroli (2013). Przyjęcie phronesis jako wiodącej koncepcji wiedzy przełamuje problemy tradycyjnego podziału teorii i praktyki. Wiedza jest bowiem w tym wypadku budowana poprzez jedność myślenia i działania, teoretyzowania i badania, ze szczególnym uwzględnieniem wymiaru etycznego, w tym świadomości konsekwencji podejmowanych działań badawczych. Zgodnie z tą ideą w centrum projektu badawczego, opartego na potrzebie zmiany, wynikającej z rzeczywistego funkcjonowania środowiska/społeczności, sytuowani są ludzie (badacze i praktycy) traktowani podmiotowo i podejmujący wspólną aktywność.

Zwiększenie znaczenia badań zogniskowanych wokół praktyki edukacyjnej wymaga również zmierzenia się z kilkoma problemami związanymi z trybem realizacji procedur badawczych czy ogólnie ujmując - uprawiania praktyki badawczej, na co zwraca uwagę T. Bauman (2017). Wiodącą kwestią jest tu świadomość dużego zróżnicowania wiedzy pedagogicznej i sposobów jej budowania oraz skutków, które mogą wynikać z tego faktu. Powołując się na opinie Jacka Piekarskiego, autorka wskazuje, że pluralizm metodologiczny związany z tworzeniem wiedzy pedagogicznej może stanowić zarówno potencjał, jak i słabość dyscypliny. Negatywnych skutków dużego zróżnicowania sposobów tworzenia wiedzy upatruje się w tendencjach do tolerantyzmu metodologicznego. Tego typu podejście pozwala na marginalizację wymagań metodologicznych, dopuszczanie deficytów uzasadniania, które manifestują się w częstszym występowaniu postaw obojętności niż krytycyzmu wobec prezentowanych postępowań badawczych. Zarzuty wobec badań empirycznych związane z niedostatecznym przestrzeganiem podstawowych reguł tworzenia wiedzy ${ }^{2}$, brakiem dyskusji wokół przyjmowanych rozwiązań metodologicznych czy wreszcie quasi-naukowością w szczególnym stopniu dotyczą badań praktycznych ${ }^{3}$, gdzie niejako z nadania podkreślana jest „bylejakość” praktyki badawczej. Bauman podkreśla, że w procesie tworzenia wiedzy pedagogicznej o znaczeniu badań nie może stanowić praktyczny cel, który im przyświeca. „Jeśli jednak badania te spełniają wszelkie wymogi metodologiczne i merytoryczne, poddawane są odpowiednim procedurom sprawdzalności ich poprawności, mogą stanowić wartościowe źródło wiedzy pedagogicznej" (Bauman 2017, s. 135). Zatem dbałość o zachowanie poprawności metodologicznej na wszystkich etapach planowania i realizacji projektu badawczego oraz uruchamianie krytycznych dyskusji

2 Wśród reguł pozwalających na utrzymanie racjonalności tworzenia wiedzy pedagogicznej J. Piekarski wymienia następujące: ciągłości wiedzy, spójności wiedzy (koherencji), kryterium translacji oraz kryterium użycia wiedzy (Piekarski 2010).

3 Rozumianych za S. Palką jako badania nieosadzone w teorii i stanowiące rodzaj raportów pozwalających rozwiązywać bieżące problemy o zasięgu lokalnym (Palka 2006). T. Bauman określa je jako badania realizowane w obszarze praktyki edukacyjnej, w której prowadzone są zarówno badania naukowe, jak i quasi-naukowe (Bauman 2017). 
w obszarze uzasadniania podejmowanych wyborów i dokonanej interpretacji wyników wydaje się jednym z kluczowych elementów w procesie rehabilitacji badań praktycznych i opartej na nich wiedzy pedagogicznej. Pamiętając o tym, że wiedza praktyczna odnosząca się do konkretnych warunków i okoliczności (bieżąca i lokalna) nie posiada znamion wiedzy uogólniającej wszelkie podobne przypadki, warto docenić jej wartość nie tylko w obszarze know how, lecz także pojawiających się uzasadnień i mechanizmów działania wyłanianych w odniesieniu do badanych procesów. Zachęcająca do podejmowania badań w obszarze pedagogicznej praktyki może być także opinia Wolfganga Brezinki, który uznał, że tak sytuowana praca naukowa jest ważna i trudna. Wymaga bowiem szerokich horyzontów myślowych (teoretycznych), rozległej wiedzy metodologicznej oraz szczególnych umiejętności pozwalających na docieranie do sedna problemów oraz formułowanie odważnych wniosków z badań (Brezinka 2005). Przedstawione rozważania, które zarysowują jedynie wybrane kierunki współczesnych debat nad miejscem badań praktycznych/stosowanych w pedagogice, stanowią punkt wyjścia do próby umieszczenia ewaluacji edukacyjnej w tej złożonej przestrzeni badawczej oraz poszukiwania odpowiedzi na pytanie o wartość wiedzy uzyskiwanej w wyniku prowadzenia badań ewaluacyjnych.

\section{Jak wiedza pedagogiczna może wyłaniać się z ewaluacji...?}

Przytoczone kontrowersje dotyczące tworzenia wiedzy pedagogicznej nawiązującej bezpośrednio do praktyki znajdują swoje odbicie w badaniach ewaluacyjnych. Choć ewaluacja jako oddzielna dyscyplina studiów i badań zaczęła rozwijać się dopiero w latach 50. i 60. ubiegłego wieku (Hogan 2009), to kilka dekad intensywnych praktyk ewaluacyjnych doprowadziło do powstania wielorakiego zbioru definicji, interpretacji, typologii i praktycznych odniesień, prezentujących czasami skrajnie odmienne podejścia badawcze. Podjęto szereg prób uporządkowania rozrastającej się literatury przedmiotu, które dały interesujące efekty, ułatwiając badaczom sprawniejsze poruszanie się w obszarze ewaluacji oraz odszukiwanie uprawomocnień wybranych przez siebie podejść. Do wspomnianej literatury należą m.in.: opracowanie Egona Guby i Yvonny S. Lincoln, prezentujące kolejne generacje ewaluacji (1989); propozycja Donny Mertens, pokazująca, w jaki sposób uprawianie tego rodzaju badań stosowanych może być osadzone w obszarze paradygmatów nauk społecznych (2010); próba zarysowania głównych dróg rozwojowych ewaluacji charakteryzujących się dominacją różnych funkcji, jakie ma ona realizować w odniesieniu do rzeczywistości społecznej, w której jest osadzona, podjęta przez Marvina C. Alkina i Christine A. Christi (2004), czy wyróżnienie czterech „fal ewaluacji" dokonane przez Everta Vedunga (2010) ${ }^{4}$. Dodatkowym elementem

$4 \mathrm{~W}$ polskiej literaturze przedmiotu kwestie te prezentowane były m.in. w opracowaniach H. Mizerka (2016), J. Nowotniak (2017), M. Maciejewskiej (2014). 
problematyzującym transparentne podejście metodologiczne w badaniach ewaluacyjnych jest sama ich specyfika, która przejawia się w fakcie, że „każda rzeczywista ewaluacja jest jednak wypadkową różnych okoliczności; w konsekwencji, poszczególne ewaluacje mogą przybierać odmienne kształty, nawet jeżeli punktem wyjścia jest ten sam partykularny typ" (za: Korporowicz 1997, s. 95). Nie oznacza to, że za każdym razem ewaluację trzeba wymyślać na nowo. Znamienne jest jednak to, że wielu wybitnych teoretyków ewaluacji nie identyfikuje się wyłącznie z jednym, partykularnym podejściem, stosując w praktyce wiele wariantów ewaluacji (House 1997). Badania ewaluacyjne zdecydowanie bardziej niż inne rodzaje badań są otwarte na próby łączenia różnych podejść i sposoby zbierania danych. Wynika to $\mathrm{z}$ dominującej w ich zakresie funkcji użyteczności, na rzecz której, w uzasadnionych przypadkach, wymogi procedur metodologicznych mogą być znacznie ograniczane. Założenia te wyraźnie różnicują praktykę ewaluacji, w ramach której Justyna Nowotniak (2017) wyróżnia badania ewaluacyjne (evaluation research, research utilization, applied research), głęboko osadzone w teorii i metodologii oraz ewaluację (evaluation utilization, evaluation use), jako praktykę uprawianą poza teorią (Mizerek 2011), przyjmującą często postać „ankietowania” powielanego bez wyraźnego zamysłu metodologicznego. W przekonaniu autorki tylko badania ewaluacyjne mogą być podstawą do tworzenia ogólnego zasobu wiedzy w danej dziedzinie. Nie można pominąć w tym miejscu również specyficznego kontekstu związanego z uprawianiem ewaluacji edukacyjnej w polskich warunkach. Ewaluacja w Polsce pojawiła się w ostatniej dekadzie XX wieku, oferując znaczny dorobek teoretycznych studiów i praktycznych podejść. Pierwszym polem polskich doświadczeń ewaluacyjnych stał się obszar edukacji. Niestety na skutek zetknięcia z silnym nurtem myślenia pozytywistycznego w polskiej szkole i o polskiej szkole zacierała się konstruktywistyczna tożsamość tych badań, zmierzając w stronę oceny i kontroli, a nie poszukiwania wiedzy o procesach edukacyjnych i budowania wokół nich dyskusji (Korporowicz 2011). Tendencje te zostały dodatkowo wzmocnione wprowadzeniem ewaluacji do struktury nadzoru pedagogicznego w roku $2009^{5}$. Przedstawione uwarunkowania wywołały skłonność do traktowania jej w uproszczony sposób, a także lekceważenia znaczenia oraz rangi badań ewaluacyjnych w edukacji zarówno przez nauczycieli, jak i badaczy (Mizerek 2017).

Co zatem może przemawiać za włączeniem ewaluacji i jej wyników w procesy tworzenia wiedzy pedagogicznej? Największą moc sprawczą mogą mieć w tym wypadku fakty, czyli wyniki badań ewaluacyjnych wnoszące interesujące poznawczo elementy do wiedzy o funkcjonowaniu szkoły. Chcę w tym miejscu przytoczyć dwa przykłady takich badań: dotyczące codzienności szkolnej, oparte na ewaluacji dokumentarnej, przeprowadzone przez Beatę Zamorską i Sławomira Krzychałę,

5 Kwestie te przedstawiłam szerzej w opracowaniu pt. Ewaluacja w polskich szkołach - od przymusu do dialogu (2018). 
oraz ewaluacje fotograficzne $\mathrm{z}$ wykorzystaniem modelu etnografii wizualnej, przedstawiane przez Justynę Nowotniak.

Proponowana przez B. Zamorską i S. Krzychałę (2008) ewaluacja dokumentarna ma charakter badania rekonstrukcyjnego, skupionego nie na poszukiwaniu wiedzy „o” działaniu, ale na wiedzy pragmatycznej, aktywowanej i używanej „w” działaniu, a jej przedmiotem są interaktywne, zespołowe i środowiskowe powiązania, tworzone w ramach badanej organizacji. Podkreślany jest także jej konwersacyjny i dialogiczny charakter, dzięki któremu może pośredniczyć w próbach „«zrozumienia» społecznego doświadczenia, w które jest się samemu zaangażowanym, oraz [...] «wyjaśniania» (interpretacji) doświadczenia innych stron" (Krzychała, Zamorska 2008, s. 38). Autorzy podkreślają także, że podjęcie projektu ewaluacji w tym schemacie wymaga każdorazowo zrekonstruowania wzoru opisu oraz zrozumienia kluczowych problemów i zwyczajów danej szkoły/organizacji, innymi słowy - poznania jej niepowtarzalnej kultury organizacyjnej. Nie mają tu zastosowania uniwersalne pomysły czy zewnętrzne rozwiązania dedykowane każdej placówce. W tym wypadku dobrą praktykę ewaluacyjną cechuje rzetelność badawcza, opierająca się m.in. na zbieraniu i analizie materiału empirycznego zgodnie z przyjętą metodą, odniesieniu do rzeczywistych problemów szkoły i naturalnym wpisywaniu się badania w zwykłą pracę szkoły, dbałości o jasność i zrozumienie procesu badawczego przez wszystkich uczestników projektu przy jednoczesnym pozostawieniu marginesu swobody, pozwalającego na kreatywne i indywidualne podejście do tematu. Potencjał takich badań wynika zarówno z różnorodnych możliwości zapisu wieloźródłowego materiału badawczego w postaci dokumentów codzienności, jak i proponowanego sposobu jego analizy. Dokumenty codzienności, które są wytworami uzewnętrznionymi, obiektywnymi, a zarazem relacyjnymi i symbolicznymi (Krzychała, Zamorska 2008, s. 67), mogą przyjmować różną formę m.in. ze względu na sposób ich utrwalania. Możemy zatem zbierać dane w postaci dokumentów: tekstowych (np. regulaminy, dzienniki, publikacje książkowe, transkrypcje rozmów), graficznych (np. zdjęcia, plany, schematy), tekstowo-graficznych (np. graffiti, plakaty), akustycznych (np. zarejestrowane wywiady, dyskusje), audiowizualnych (np. filmy przygotowane przez uczniów, nagrania). Dokumenty mogą różnić się też sposobem „zakotwiczenia” w społecznej rzeczywistości. Pozyskuje się dokumenty zebrane, które stanowią część normalnej praktyki społecznej oraz dokumenty tworzone przy okazji rutynowego działania, albo dokumenty rejestrujacce - tworzone w ramach rejestrowania prowadzonych obserwacji za pomocą adekwatnych technik, a także dokumenty moderowane oparte na zapisie aranżowanych przez badacza sytuacji (np. dyskusji grupowych czy reportaży zdjęciowych) oraz dokumenty osobiste - zebrane np. w postaci portfolio (Krzychała, Zamorska 2008, s. 70-75). Tak szeroko rozumiany materiał empiryczny poddawany jest interpretacji dokumentarnej, na którą składa się analiza formułująca (opisowa) pokazująca treści wypowiedzi i analiza refleksywna (formalna) skupiająca się na formie wypowiedzi, która nadaje jej znaczenie niezależne od treści, 
a czasami wprost odwraca to znaczenie (Krzychała, Zamorska 2008, s. 118-119). Prowadząc projekty w ramach ewaluacji dokumentarnej, można obserwować m.in. procesy społeczno-kulturowego życia szkoły, które odsłaniają nowe, interesujące obszary badawcze. Autorzy pokazali, że praca projektowa może stanowić „lustro” nauczycielskiego stylu pracy. W opracowaniu przygotowanym w oparciu o jedną z przeprowadzonych w szkole ewaluacji pokazywane są mechanizmy odkrywania zasad współpracy nauczycieli. Dwie nieformalne grupy pedagogów, które na co dzień funkcjonowały w szkole, wyraźnie ujawniły się też w ramach zespołu ewaluacyjnego, pokazując dominację jednej z nich. Dominacja ta i związane z nią rozbieżności zdań nie ujawniały się w dyskusjach na forum. Osoby ze „słabszej” grupy rozmawiały z badaczami indywidualnie po zakończeniu spotkań. Co więcej, przygotowane przez uczniów tej szkoły reportaże zdjęciowe pokazały, że „uczniowie już znacznie wcześniej nie tylko spostrzegli koniunktywne zasady zhierarchizowania relacji w zespole nauczycieli, ale przyjęli podobny klucz do regulowania relacji między uczniami. W szkole funkcjonowała również dominująca grupa uczennic" (Krzychała, Zamorska 2008, s. 113). Pojawia się tu rzadko podejmowany w badaniach pedagogicznych moment ujawnienia wzajemnych powiązań pomiędzy strukturami społecznymi tworzonymi przez dwie najważniejsze społeczności szkoły: nauczycieli i uczniów. W innym przykładzie analiza reportaży zdjęciowych przygotowanych przez uczniów pozwala zobaczyć, jak sytuują się oni w przestrzeni szkoły. Dokonywana odrębnie interpretacja pojedynczych zdjęć i całej reportażowej „opowieści” pokazuje znaczenia nadawane przez uczniów relacjom szkolnym. Dziewczęta ujawniają w nim swoje dopasowanie do kontekstu szkoły, bez roszczeń do zajęcia uprzywilejowanej pozycji, podkreślając jednocześnie wagę wzajemnej bliskości. Natomiast chłopcy pokazani są jako aktywni i spontaniczni. Nie są konformistycznie „wciśnięci” w przestrzeń szkoły, jest ona tłem lub potencjalną sceną ich działania. Znaczącym elementem ich aktywności jest zaangażowanie w zwrócenie na siebie uwagi. Kompozycja całego plakatu/reportażu ujawnia natomiast wątki krytyki i dystansowania się względem szkoły, ograniczane jednak przez tendencje do konformistycznego dostosowania się do jej wymogów. W roli tytułu występuje jeden z podstawowych celów instytucji oświatowych: szkoła uczy i wychowuje, zapisany z błędami ortograficznymi („Szkoła óczy i fyhofóie...”). Świat szkoły uzupełniony jest także o relacje z ulubionymi nauczycielami. Zatrzymana w opowieści szkolna codzienność uczniów ujawnia jej rzeczywiste wymiary.

Z kolei Justyna Nowotniak (2012) przedstawia możliwości wykorzystywania etnografii wizualnej jako metody prowadzenia badań pedagogicznych, w tym również edukacyjnej ewaluacji. Etnografia wizualna opiera się na krytycznym rozumieniu kultury wizualnej, która ma charakter interakcyjny i wiąże się z wartościowaniem. Pokazanie różnych praktyk widzenia ściśle związanych z określonym kontekstem może prowadzić do odwzorowania wielostronnych relacji, jakie stają się udziałem członków danej społeczności w trakcie wytwarzania wizualnych artefaktów, manipulowania nimi i ich interpretowania. Kultura wizualna jest zatem 
konstrukcją społeczną, a jej odkrywanie za pomocą obrazu pozwala na wyjście poza schematy i daje szanse dotarcia do wiedzy ukrytej. Jak podkreśla autorka, „Kultura wizualna szkoły nie jest wystarczająco eksplorowana badawczo w naszym kraju. [...] Nagminnym grzechem popełnianym przez wielu badaczy jest praktyka opisywania świata szkoły «zza biurka», na podstawie badań sondażowych. Prowadzi to do petryfikacji utrwalonego obrazu rzeczywistości. Obrazu, który jest jedynie platońskim cieniem zdarzeń realnie występujących za szkolną bramą" (Nowotniak 2012, s. 63). Propozycja zastosowania w edukacji tzw. fotoewaluacji, opartej na schemacie badawczym etnografii wizualnej, pozwala przede wszystkim na uwzględnianie uczniowskiej perspektywy w badaniach szkoły. To uczniowie są bowiem bezpośrednio angażowani w tworzenie fotograficznych relacji o szkole i zachęcani do prowadzenia dyskusji wokół istotnych dla nich kwestii. Fotografowanie staje się w tym wypadku podstawą do nawiązania relacji badacza z uczniami jako członkami swoistej kultury szkolnej i głębszego zajrzenia w jej wnętrze. Interpretacja uzyskanego materiału empirycznego może przebiegać na różnych poziomach: $\mathrm{w}$ wymiarze estetycznym, historycznym, interpersonalnym czy kulturowym. Jednym $\mathrm{z}$ obszarów eksplorowanych $\mathrm{w}$ fotoewaluacjach jest badanie szkolnej przestrzeni i jej zagospodarowania. Pozwala ona na określenie obecności, częstotliwości czy proporcji usytuowanych w niej obiektów, a także na ich uporządkowanie zgodnie $\mathrm{z}$ nadawaną im przez uczniów hierarchią ważności i wartościowaniem. Na osadzenie zebranych informacji w kontekście całości przekazu pozwala wymiar relacji, odpowiadający na pytanie: co jest z czym i jak powiązane (w oparciu o zasady analizy przekazów masowych G. Gerbnera). Wśród wyników badań zaprezentowanych przez J. Nowotniak w przytaczanym opracowaniu warto zwrócić uwagę na jeden $\mathrm{z}$ dominujących motywów przejawiających się w wypowiedziach uczniów, jakim jest władza sprawowana przez nauczycieli nad przestrzenią. Motyw ten pojawia się m.in. na fotografiach przedstawiających kraty i okna. Roztaczające się za nimi widoki symbolizują zdaniem młodych ludzi „uwolnienie”, „wydostanie się spod nadzoru”. Jednak dla większości uczniów szkoła stanowi zamkniętą i wyizolowaną przestrzeń, wydzieloną ze świata zewnętrznego i podzieloną na terytoria, których granice są jasno ustalone. Młodzież dzieli tę przestrzeń w różny sposób. Wyróżniają np. terytoria „swoje”, „obce” i „neutralne” lub strefy „publiczną", „prywatną” i „zdegradowaną” (Nowotniak 2012, s. 120). Te $\mathrm{i}$ inne dane uzyskane $\mathrm{w}$ ramach przedstawianych badań pozwoliły na ujawnienie funkcjonujących w szkole ukrytych programów wynikających $\mathrm{z}$ określonego wykorzystania rozwiązań architektonicznych i organizacji przestrzeni. Pokazały jednocześnie brak dbałości o rozpoznanie potrzeb przestrzennych dzieci i młodzieży oraz strategie, jakie przyjmują uczniowie, aby odnajdywać swoje miejsce w szkole. „Zdjęcia dodały wiele ważnych informacji na temat korzystania z przestrzeni szkoły (swoistej topografii szkolnej przestrzeni) [...] odsłoniły „miejsca pobytu uczniów" poza terenem szkoły [...] dzięki fotografiom powstała mapa miejsc odwiedzanych przez uczniów i problemów z tym związanych" (Nowotniak 2012, 
s. 225). Fotografowanie zastosowane jako technika pracy odsłania też potencjał refleksyjności uczniów, który często zaskakuje nauczycieli. Konfrontuje też dorosłych z uwikłaniem wynikającym z braku otwartości na punkt widzenia innych uczestników życia szkolnego czy grami wynikającymi ze specyficznych stosunków władzy. Zatrzymany na fotografii obraz szkolnej rzeczywistości pozwala na dostrzeżenie faktów i procesów, które wymykają się narracjom. Często jest to zaskakujące zarówno dla praktyków, jak i badaczy.

Toczone na polu pedagogiki ogólnej i metodologii badań dyskusje dotyczące tworzenia wiedzy pedagogicznej opartej na badaniach empirycznych, a szczególnie badaniach praktycznych/stosowanych nie należą obecnie do rzadkości. Wydaje się to szczególnie istotne w sytuacji, kiedy każda szkoła jako instytucja i organizacja może żyć własnym życiem. Dawne przyzwyczajenia związane z obrazem tradycyjnej edukacji skłaniającej do budowania na podstawie badań normatywnych przesłanek pokazujących, „jak powinno być” w każdej placówce danego typu, ustępują miejsca poszukiwaniom tego, „jak może być” w szkole, która ma własną „duszę" (Tuohy 2002). Badania stosowane w rozumieniu applied research (Neuman 2014), realizujące praktyczne cele i skierowane w pierwszym rzędzie do praktyków, mogą zarówno wspierać zmiany konkretnej instytucji, jak też poprzez bezpośredni wgląd w dziejące się w niej procesy pokazywać rzeczywiste mechanizmy jej funkcjonowania. Przyglądając się możliwościom, jakie tworzy badanie ewaluacyjne prowadzone w szkołach przez praktyków bezpośrednio zaangażowanych w życie swoich placówek, trudno oprzeć się wrażeniu, że nie korzystając z takich badań, wiele tracimy. Oczywiście, korzystanie z wyników ewaluacji wymaga ostrożności i postulowanej przez metodologów dbałości o zachowanie wszelkich standardów badawczych. Praktyki ewaluacyjne podsuwają ciekawe rozwiązanie tych kwestii, proponując prowadzenie badań w zespołach złożonych z praktyków i badaczy. Badacz występujący w takim wypadku w roli „krytycznego przyjaciela” wspomaga nauczycieli i uczniów w procesie konstruowania i realizowania projektu badawczego oraz proponuje metody analizy uzyskanych danych. Szczególnie interesujący wydaje się nurt ewaluacji mieszczący się w czwartej generacji ewaluacji - ewaluacji dialogicznej i partycypacyjnej. Jakościowe podejścia badawcze pozwalają w tym wypadku na zainicjowanie potrzebnego w szkołach dialogu, dotyczącego ich codziennego funkcjonowania oraz ujawnienie istotnych procesów społecznych i edukacyjnych, które stanowią ważny element wiedzy pedagogicznej.

\section{Bibliografia}

Alkin M. C., Christi C. A. (2004). An Evaluation Theory Tree, dostępny na: http:// sagepub.com/upm-data/5074_Alkin_Chapter_2.pdf (otwarto: 1.07.2014). 
Arystoteles (1983). Metafizyka, tłum. Leśniak K. Warszawa: PWN.

Bauman T. (2017). Badanie empiryczne jako źródło i tworzywo wiedzy pedagogicznej. W: Kubinowski D., Chutorański M. (red.). Pedagogika jako humanistyczno-społeczna nauka stosowana: konsekwencje metodologiczne. Kraków: Oficyna Wydawnicza „Impuls”.

Brezinka W. (2005). Wychowanie i pedagogika $w$ dobie przemian kulturowych. Podręcznik akademicki, tłum. Kochanowicz J. Kraków: Wydawnictwo WAM.

Czerepaniak-Walczak M. (1997). Rola krytycznej refleksji w procesie poznania pedagogicznego. Aksjologiczne aspekty przedmiotu poznania. W: Kukołowicz T., Nowak M. (red.). Pedagogika ogólna. Problemy aksjologiczne. Lublin: KUL.

Guba E. G., Lincoln Y. S. (1989). Fourth Generation Evaluation. London: Sage.

Hejnicka-Bezwińska T. (2017). Kontrowersje teoretyczno-metodologiczne zmian w pojmowaniu praxis. W: Kubinowski D., Chutorański M. (red.). Pedagogika jako Humanistyczno-społeczna nauka stosowana: konsekwencje metodologiczne. Kraków: Oficyna Wydawnicza „Impuls”.

Hogan L.R. (2009). The Historical Development of Programme Evaluation. Exploring the Past and Present. „Online Journal of Workforce Education and Development”, t. 2, nr 4, s. 1-10.

House E. R. (1997). Ewaluacja i jej uprawomocnianie. Główne podejścia. W: Korporowicz L. (red.). Ewaluacja w edukacji. Warszawa: Oficyna Naukowa.

Konarzewski K. (200o). Jak uprawiać badania oświatowe. Metodologia praktyczna. Warszawa: WSiP.

Korporowicz L. (2011). Zmienne losy polskiej ewaluacji. Pomiędzy nadzieja, animacją i konfuzja. W: Niemierko B., Szmigiel M. K. (red.). Ewaluacja w edukacji: koncepcje, metody, perspektywy. Kraków: GRUPA TOMAMI.

Korporowicz L. (red.). (1997). Ewaluacja w edukacji. Warszawa: Oficyna Naukowa.

Krzychała S., Zamorska B. (2008). Dokumentarna ewaluacja szkolnej codzienności. Wrocław: Wydawnictwo Naukowe Dolnośląskiej Szkoły Wyższej.

Kwieciński Z. (200o). Tropy - ślady - próby. Studia i szkice z pedagogiki pogranicza. Poznań-Olsztyn: Wydawnictwo Edytor.

Leppert R. (2001). Potoczne pojmowanie praktyczności pedagogiki. W: „Teraźniejszość - Człowiek - Edukacja”, nr specjalny: Normatywizm - Etyczność-Zaangażowanie. Współczesne dyskusje o praktyczności pedagogiki.

Maciejewska M. (2014). Badania ewaluacyjne w edukacji i ich konteksty w akademickim kształceniu nauczycieli i pedagogów. „Opuscula Sociologica”, nr 4, s. 31-43.

Maciejewska M. (2018). Ewaluacja w polskich szkołach - od przymusu do dialogu. „Zarządzanie Publiczne”, nr 1 (41).

Mertens D. M. (2010). Research and Evaluation in Education and Psychology. London: Sage Publications.

Mizerek H. (2010). Koloryt współczesnych badań ewaluacyjnych. W: Kędzierska H. (red.). Jakościowe inspiracje w badaniach edukacyjnych. Olsztyn: Wydawnictwo UWM. 
Mizerek H. (2011). Tam, gdzie kończą się zaklęcia, a zaczyna ewaluacja. W: Niemierko B., Szmigiel M. K. (red.). Ewaluacja w edukacji: koncepcje, metody, perspektywy. Kraków: GRUPA TOMAMI.

Mizerek H. (2016). Ewaluacja edukacyjna w Polsce. Trajektorie, perspektywy i dylematy rozwoju. „Zarzadzanie Publiczne”, 1 (33).

Mizerek H. (2017). Ewaluacja edukacyjna. Interdyskursywne dialogi i konfrontacje. Kraków: Oficyna Wydawnicza „Impuls”.

Neuman W. L. (2014). Social Research Methods: Qualitative and Qantitative Approaches. London.

Nowak-Dziemianowicz M. (2013). W poszukiwaniu nowej pedagogiki, nowej edukacji, nowej szkoły - reminiscencje. W: Cervinkova H., Gołębniak B. D. (red.). Edukacyjne badania w działaniu. Warszawa: Wydawnictwo Naukowe Scholar.

Nowotniak J. (2012). Etnografia wizualna $w$ badaniach i praktyce pedagogicznej. Kraków: Oficyna Wydawnicza „Impuls”.

Nowotniak J. (2017). Miejsce, swoistość, metodologiczna różnorodność badań ewaluacyjnych $w$ pedagogice - konsekwencje dla pedagogii. W: Kubinowski D., Chutorański M. (red.). Pedagogika jako humanistyczno-społeczna nauka stosowana: konsekwencje metodologiczne. Kraków: Oficyna Wydawnicza „Impuls”.

Palka S. (2006). Metodologia. Badania. Praktyka pedagogiczna. Gdańsk: Wydawnictwo GWP.

Palka S. (red.). (2010). Podstawy metodologii badań w pedagogice. Gdańsk: Wydawnictwo GWP.

Piekarski J. (2010). Kryteria waloryzacji krytyki badawczej- między inhibicja metodologiczna a permisywnym tolerantyzmem. W: Piekarski J., Urbaniak-Zając D., Szmidt K. J. (red.). Metodologiczne problemy tworzenia wiedzy w pedagogice. Oblicza akademickiej praktyki. Kraków: Oficyna Wydawnicza „Impuls”.

Piekarski J., Urbaniak-Zając D., Szmidt K. J. (red.). (2010). Metodologiczne problemy tworzenia wiedzy w pedagogice. Oblicza akademickiej praktyki. Kraków: Oficyna Wydawnicza „Impuls”.

Rubacha K. (2003). Edukacja jako przedmiot pedagogiki i jej subdyscyplin. W: Kwieciński Z., Śliwerski B. (red.). Pedagogika. Podręcznik akademicki. t. 1. Warszawa: PWN.

Rubacha K. (2008). Metodologiczna struktura przedmiotu badań pedagogiki. W: Rubacha K. (red.). Konceptualizacje przedmiotu badań pedagogiki. Kraków: Oficyna Wydawnicza „Impuls”.

Rubacha K. (2008). Metodologia badań nad edukacją. Warszawa: Wydawnictwa Akademickie i Profesjonalne.

Rutkowiak J. (2001). Społeczne funkcjonowanie pedagogiki; czasowy wymiar etyczności. W: „Teraźniejszość - Człowiek - Edukacja”, nr specjalny: Normatywizm Etyczność - Zaangażowanie. Współczesne dyskusje o praktyczności pedagogiki.

Tuohy D. (2002). Dusza szkoły. O tym, co sprzyja zmianie i rozwojowi. Warszawa: PWN. 
Urbaniak-Zając D. (2008). Rzeczywistość pedagogiczna a sposoby jej poznawaniaperspektywa interpretacyjna. W: Rubacha K. (red.). Konceptualizacje przedmiotu badań pedagogiki. Kraków: Oficyna Wydawnicza „Impuls”.

Vedung E. (2010). Four Waves of Evaluation Diffusion. „Evaluation”, nr 16 (3), s. $263-270$.

\title{
EVALUATION STUDIES IN EDUCATION AS A SOURCE OF PEDAGOGICAL KNOWLEDGE
}

\begin{abstract}
In debates undertaken in the general pedagogy area, a significant place is occupied by methodological issues related to searching for new possibilities of generating pedagogical knowledge. It is a result of various conditions. Most of all, it is a response to changes that take place in widely defined education and newly posed questions about the usefulness of pedagogical knowledge. It is also an important fragment of creating the discipline's identity, entering into the dynamic process of its internal changes and development. There are new questions related to the subject's conceptualisation, new ways of formulating research problems, which requires new methodological solutions. The study presented is meant to be a voice in the debate over situating research defined as applied/ practical regarding the needs of pedagogical practice as well as pedagogical theory. Special emphasis was laid on evaluation research in education, which in the author's opinion generates many possibilities of identifying consequential pedagogical issues.
\end{abstract}

Keywords: applied research, evaluation in education, general pedagogy, methodology of educational science.

Monika Maciejewska - doktor nauk humanistycznych, adiunkt w Katedrze Pedagogiki Ogólnej na Wydziale Nauk Społecznych Uniwersytetu Warmińsko-Mazurskiego w Olsztynie. Zajmuje się kwestiami zmian zachodzących w polskich szkołach, a szczególnie możliwościami wykorzystania badań stosowanych (diagnoza, ewaluacja, badania w działaniu) do tworzenia przestrzeni sprzyjających rozwojowi społeczności szkolnych. Interesuje się problematyką szkolnictwa wyższego, w tym kształcenia i doskonalenia zawodowego nauczycieli. Zainteresowania badawcze koncentruje wokół ewaluacji edukacyjnej oraz pedagogiki szkoły wyższej. Adres do korespondencji: Katedra Pedagogiki Ogólnej UWM, ul. Żołnierska 14, 10-561 Olsztyn. Adres e-mailowy: monika.maciejewska@uwm.edu.pl. 